\title{
Komitmen Organisasi Auditor, Kelelahan, dan Keinginan untuk Pindah: Suatu Penelitian Replikasi
}

\author{
Dito Aditia Darma Nasution \\ Universitas Pembangunan Panca Budi \\ Medan, Indonesia \\ ditoaditia@dosen.pancabudi.ac.id
}

\author{
Puja Rizqy Ramadhan \\ Universitas Pembangunan Panca Budi \\ Medan, Indonesia \\ pujarizqy@dosen.pancabudi.ac.id
}

\author{
Erlina \\ Universitas Sumatera Utara \\ Medan, Indonesia \\ erlinaroesli@yahoo.co.id
}

Corresponding Author : Dito Aditia Darma Nasution

Submitted: 22 Juni 2020

Accepted: 9 Agustus 2020

Published: 9 Agustus 2020

\begin{abstract}
ABSTRAK
Penelitian ini adalah penelitian replikasi dari penelitian yang dilakukan oleh Herda \& Lavelle (2012) yang meneliti tentang komitmen organisasi auditor, kelelahan (burnout) dan keinginan untuk pindah (turnover intention). Penelitian replikasi yang kami lakukan adalah sebuah alternatif pengukuran komitmen yang telah dikonsep dan telah divalidasi secara empiris dalam literatur organisasi pengukuran komitmen KUT (Klein, et al, Unidimensional, Target-Free). Penelitian ini dilakukan pada 110 orang auditor dari perusahaan akuntan publik berskala nasional (di luar 4 besar). Tanggapan mereka di kumpulkan melalui survey virtual internet dengan tanpa nama pada Februari 2020. Hasil dari penelitian replikasi yang telah kami lakukan menunjukkan bahwa adanya konsistensi yang tinggi dengan yang dilaporkan dalam penelitian asli, serta menunjukan bahwa hasil yang dilaporkan memiliki korelasi yang tinggi dan juga menunjukkan bahwa metode KUT dapat digunakan dengan efektif didalam konteks penelitian akuntansi keprilakuan. Penelitian yang kami lakukan ini juga akan membahas beberapa konsep potensial dan manfaat praktis dari KUT sebagai bahan pertimbangan penelitian akuntansi keprilakuan dalam sistem akuntansi.
\end{abstract}

Keywords : Komitmen Organisasi Auditor, Kelelahan, Keinginan untuk Pindah

\section{PENDAHULUAN}

Tujuan dari penelitian ini adalah untuk mereplikasi penelitian terdahulu yakni penelitian dari Herda \& Lavelle (2012) serta hasil dari komitmen organisasi (perusahaan). Penelitian Herda \& Lavelle (2012) dilakukan berdasarkan pada teori pertukaran sosial, dimana hubungan interaksi sosial yang positif menghasilkan kewajiban (Wulandari \& Nuryanto, 2018). Berdasarkan teori pertukaran sosial, penelitian Herda \& Lavelle (2012) menempatkan dan menemukan bahwa komitmen auditor pada perusahaan berasal dari persepsi mereka tentang perlakuan adil dan dukungan yang mereka terima dari perusahaan akuntan mereka. Herda \& 
Lavelle (2012) berhipotesa dan menemukan bahwa komitmen pada perusahaan, pada akhirnya akan mengarah ke tingkat kelelahan (yang diukur dalam hal kelelahan emosional) dan keinginan untuk pindah yang lebih rendah. Temuan ini menggaris bawahi tentang pentingnya perlakuan adil dalam perusahaan yang menimbulkan pertukaran sosial diantara auditor dan perusahaan, yang memberikan keuntungan bagi keduanya.

Penelitian kami ini memaparkan hasil yang konsisten dengan yang dilaporkan pada penelitian Herda \& Lavelle (2012). Kami mengambil sampel sebanyak 110 auditor dan mengikuti metodologi yang sama seperti Herda \& Lavelle (2012) dengan satu pengecualian. Kami mengganti skala komitmen yang digunakan dipenelitian sebelumnya, yang mana menggunakan pengukuran komitmen tradisional, menjadi menggunakan pengukuran komitmen versi KUT (Klein, et al, Unidimensional, Target-Free) yaitu sebuah metode pengukuran alternatif yang sedang popular dan dapat dibuktikan secara empiris dalam sebuah literature organisasi (Chaddha \& Navjayot, 2017). Hasil dengan metode KUT selaras dengan penelitian sebelumnya, yang menunjukkan tingkat korelasi yang tinggi untuk hasil Herda \& Lavelle (2012), didukung oleh validitas konvergen untuk menilai kostruk komitmen, dan mengenalkan metode KUT dalam literature ilmiah Akuntansi (Aubert, et al, 2019).

Bagian pada penelitian ini terdiri atas diskusi singkat pada teori penelitian sebelumnya yang berdasarkan pada perkiraan dan metodologi penelitian, yang diikuti oleh kesimpulan hasil empiris yang kami lakukan. Pada akhirnya, kami menyarankan agar penelitian akuntansi khususnya terkait dengan akuntansi keprilakuan di masa yang akan datang mempertimbangkan penggunaan metode KUT dengan segala kelebihannya.

\section{TINJAUAN PUSTAKA,}

Herda \& Lavelle (2012) menitik beratkan bagaimana persepsi perlakuan adil kepada karyawan dapat membantu mengembangkan hubungan interaksi sosial yang kuat antara auditor dan perusahaan, dimana hal ini dapat menguntungkan bagi organisasi (misalnya menurunkan tingkat kelelahan dan keinginan untuk pindah perusahaan). Karena itu, teori pertukaran sosial menjadi dasar teori dalam penelitian.

Teori pertukaran sosial ditulis pertama kali pada tahun 1920-an dan telah dipakai diberbagai disiplin ilmu. Sederhananya, pertukaran sosial merupakan interaksi positif yang berkelanjutan dan menciptakan kewajiban (Ravas, 2015). Hubungan pertukaran sosial digambarkan sebagai subjektif, berorientasi pada hubungan antara pegawai dan perusahaan yang ditandai dengan adanya saling percaya, fokus jangka panjang, komitmen tidak terbatas (Maslova et al, 2017). Komitmen dapat dilihat sebagai indikator sikap sejauh mana karyawan menganggap diri mereka memiliki hubungan yang berkualitas dengan pimpinan mereka (Wisdom \& Oyebisi, 2017). Dengan demikian, penelitian ini menggunakan komitmen organisasi untuk mengukur kualitas pertukaran sosial antara auditor dan perusahaan dan memperediksi bahwa persepsi perlakuan adil perusahaan dan dukungan akan menghasilkan komitmen yang lebih besar kepada perusahaan, yang pada akhirnya akan menurunkan tingkat kelelahan dan keinginan untuk pindah dari perusahaan. Pada gambar 1 berikut dapat dijelaskan replikasi dari teori dan hipotesis terkait yang diuji oleh Herda \& Lavelle (2012). 


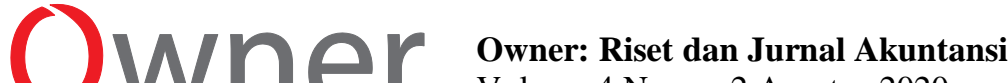

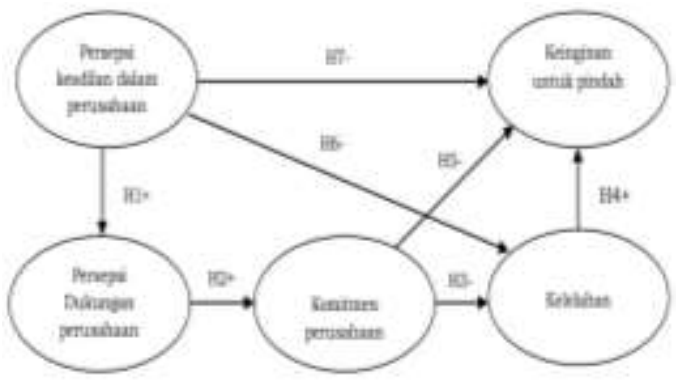

Gambar 1. Hipotesis Hubungan Kelelahan dan Keinginan untuk Pindah

\section{METODE PENELITIAN}

Sampel Herda \& Lavelle (2012) terdiri dari 204 auditor dari dua perusahaan akuntan publik yang mana satu berskala nasional (diluar 4 besar) dan satu lagi berskala internasional. Tanggapan mereka dikumpulkan melalui survey virtual internet dengan tanpa nama, pada Agustus 2011. Sampel pada penelitian ini terdiri dari 110 orang auditor dari dua perusahaan akuntan publik berskala nasional (diluar 4 besar). Tanggapan mereka di kumpulkan melalui survey virtual internet dengan tanpa nama pada Februari 2020.

Pengukuran yang digunakan dalam penelitian ini identik dengan yang digunakan didalam penelitian Herda \& Lavelle (2012) dengan satu pengecualian. Pengukuran komitmen (Allen and Meyer 1990) digunakan dalam penelitian sebelumnya. Penelitian replikasi kami ini menampilkan pengukuran komitmen alternatif yang baru-baru ini dikemukakan dan telah divalidasi secara empiris didalam literatur organisasi. KUT mengkonsep ulang komitmen dengan lebih baik untuk membedakannya dari konstruk lain yang tampak serupa meliputi identifikasi, untuk meningkatkan penerapannya di semua target tempat kerja, dan menjembatani pengukuran berkesinambungan atas berbagai jenis komitmen di masa mendatang (Mitrík, 2019). KUT mendefinisikan komitmen sebagai ikatan kemauan secara psikologi yang mencerminkan dedikasi dan tanggung jawab atas target tertentu (Singgiet al, 2017). Konsep ini dapat diterapkan pada berbagai tempat kerja baik itu perusahaan, tim, orang pribadi, program, keputusan, dll. Mereka berargumentasi bahwa seseorang dapat secara berkesinambungan berkomitmen pada beberapa target dan bahwa target yang berbeda tersebut mewakili fokus atau referensi yang berbeda, tapi tidak mewakili bentuk, model dan dimensi dari komitmen KUT(Desaiet al, 2016).

Selaras dengan konsep yang dijelaskan sebelumnya, metode KUT menghadirkan metode alternatif dalam pengukuran komitmen. Metode KUTmelakukan uji empiris dengan menggunakan 5 variabel, dengan partisipan 2.487 orang, dengan menguji berdasarkan 8 target komitmen, dan beberapa komitmen sebelumnya, termasuk metode pengukuran AllenMeyer dan Mowday-Porter,dan pengujian konteks lainnya. Pengujian tersebut menunjukkan bahwa metode KUT memiliki validitas konstruk yang unggul, konsistensi internal, faktor stuktur, dan membedakan validitas relative dari pengukuran sebelumnya.

\section{HASIL DAN PEMBAHASAN}

Tabel 1 menunjukkan statistik deskriptif, reliabilitas, dan korelasi dari berbagai variabel. Hasilnya mirip dengan yang dilaporkan oleh Herda \& Lavelle (2012). Cronbach alpha untuk pengukuran komitmen perusahaan menggunakan KUT adalah 0,97, mengindikasikan bahwa konsistensi internal yang sangat baik (Zucolotto \& Teixeira, 2014). Untuk lebih detailnya dapat dilihat pada tabel 1 . 
Tabel 1. Statistik Deskriptif, Keandalan, dan Korelasi (Personal) antara Variabel Independen dan Dependen

\begin{tabular}{|l|l|l|l|l|l|l|l|l|l|l|}
\hline \multicolumn{1}{|c|}{ Variabel } & Mean & Median & SD & Min & Max & $\mathbf{1}$ & $\mathbf{2}$ & $\mathbf{3}$ & $\mathbf{4}$ & $\mathbf{5}$ \\
\hline $\begin{array}{l}\text { Persepsi } \\
\text { perlakuan adil }\end{array}$ & 5,91 & 6,00 & 1,06 & 1,00 & 7,00 & $(0,97)$ & & & & \\
\hline $\begin{array}{l}\text { Persepsi akan } \\
\text { dukungan }\end{array}$ & 5,22 & 6,00 & 1,33 & 1,00 & 7,00 & $0,79^{* *}$ & $(0,85)$ & & & \\
\hline $\begin{array}{l}\text { Komitmen } \\
\text { pada firm }\end{array}$ & 4,81 & 5,75 & 1,32 & 1,00 & 7,00 & $0,55^{* *}$ &, $053^{* *}$ & $(0,97)$ & & \\
\hline $\begin{array}{l}\text { Kelelahan } \\
\text { Keinginan } \\
\text { untuk pindah }\end{array}$ & 4,38 & 4,33 & 1,57 & 1,00 & 7,00 & $-0,40^{* *}$ & $-0,37^{* *}$ & $-0,45^{* *}$ & $(0.90)$ & \\
\hline
\end{tabular}

** Menunjukkan $\mathrm{p}<0.01$ (dua angka dibelakang koma)

Skala Reliabilitas (Cronbach's a) ditandai dengan angka dalam kurung

Seperti dalam penelitian sebelumnya, penelitian kami ini menggunakan pemodelan persamaan struktur untuk menilai uji ketepatan model dan uji nilai estimasi. Kami menggunakan indeks ketepatan model yang sama seperti penelitian sebelumnya untuk mengevaluasi ketepatan model: Goodness Fit Index (GFI), Comparative Fit Index (CFI), Incremental Fit Index (IFI) dan Root Mean Square Error of Aproximation (RMSEA). Nilai diatas 0.90 untuk GFI, CFI, dan IFI, dan Nilai RMSEA dibawah 0.08 masih dapat diterima sebagai model yang fit(Hullah, 2012). Hasil model pengukuran dalam penelitian ini menunjukan ketepatan model dengan data $(\mathrm{GFI}=0.90 ;$ CFI $=1.00 ;$ IFI $=1.00$; RMSEA $=0.03)$. Semua dari variabel laten diukur secara efektif oleh masingmasing indikator, karena semua loading faktor menunjukan signifikan secara statistic $(\mathrm{p}<0.001)$. Loading factor terstandarisasi KUT jarak item dari 0.92 sampai 0.95 .

Model struktur yang dihipotesis kan Herda \& Lavelle (2012) juga menunjukan kecocokan model dengan data di dalam penelitian ini $(\mathrm{GFI}=0.90$; $\mathrm{CFI}=0.99 ; \quad \mathrm{IFI}=0.99 ; \quad \mathrm{RMSEA}=0.04$ ). Tabel 2 membandingkan hasil dari model struktur dari penelitian sebelumnya dengan penelitian kami ini untuk masingmasing tujuh hipotesis dengan melaporkan estimasi-estimasi parameter dan level signifikan. 
Tabel 2. Hipotesis dan Perbandingan Hasil

\begin{tabular}{|l|c|c|c|c|}
\hline \multirow{2}{*}{ Hypotesis } & \multicolumn{2}{|c|}{ Herda \& Lavelle } & \multicolumn{2}{c|}{ Replikasi } \\
\cline { 2 - 5 } & $\begin{array}{l}\text { Hypotesis } \\
\text { Supported? }\end{array}$ & $\begin{array}{c}\text { Standardized } \\
\text { effect }\end{array}$ & $\begin{array}{c}\text { Hypotesis } \\
\text { Supported? }\end{array}$ & $\begin{array}{c}\text { Standardized } \\
\text { effect }\end{array}$ \\
\hline $\begin{array}{l}\text { H1: Persepsi perlakuan adil } \\
\text { perusahaan memiliki hubungan positif } \\
\text { terhadap persepsi dukungan } \\
\text { perusahaan }\end{array}$ & Yes & $0.890^{* * *}$ & Yes & $0.864^{* * *}$ \\
\hline $\begin{array}{l}\text { H2: Persepsi dukungan perusahaan } \\
\text { memiliki hubungan positif terhadap } \\
\text { komitmen perusahaan }\end{array}$ & Yes & $0.770^{* * *}$ & Yes & $0.580^{* * * *}$ \\
\hline $\begin{array}{l}\text { H3: Komitmen perusahaan memiliki } \\
\text { hubungan negatif terhadap kelelahan }\end{array}$ & Yes & $-0.313^{* *}$ & Yes & $-0.350^{* * *}$ \\
\hline $\begin{array}{l}\text { H4: Kelelahan memiliki hubungan } \\
\text { positif terhadap keinginan pindah }\end{array}$ & Yes & $0.223^{* *}$ & Yes & $0.163^{* * *}$ \\
\hline $\begin{array}{l}\text { H5: Komitmen perusahaan memiliki } \\
\text { hubungan negatif terhadap keinginan } \\
\text { pindah }\end{array}$ & Yes & $-0.408^{* * *}$ & Yes & $-0.679^{* * *}$ \\
\hline $\begin{array}{l}\text { H6: Persepsi perlakuan adil } \\
\text { perusahaan memiliki hubungan } \\
\text { negatif terhadap kelelahan }\end{array}$ & Yes & $-0.336^{* * *}$ & Yes & $-0.228^{* * * *}$ \\
\hline $\begin{array}{l}\text { H7: Persepsi perlakuan adil } \\
\text { perusahaan memiliki hubungan } \\
\text { negatif terhadap keinginan pindah }\end{array}$ & Yes & $-0.215^{* *}$ & No & 0.054 \\
\hline$* *$ Menunjukkan p $<0.05$ dan *** menunjukkan p < 0.001 & & \\
\hline
\end{tabular}

** Menunjukkan $\mathrm{p}<0.05$ dan $* * *$ menunjukkan $\mathrm{p}<0.001$

Semua koefisien jalur, signifikan dengan estimasi parameter dengan satu pengecualian. Herda \& Lavelle (2012) menempatkan dan menemukan persepsi perlakuan adil perusahaan memiliki hubungan negatif dengan keinginan untuk pindah perusahaan. Meskipun Tabel 1 melaporkan hubungan negatif yang signifikan diantara persepsi perlakuan adil perusahaan dan keinginan untuk pindah $(\mathrm{r}=-0.35 ; \mathrm{p}<0.001)$, hal ini menunjukan bahwa KUT dapat digunakan dengan efektif di penelitian akuntansi keprilakuan dimasa mendatang.

\section{KESIMPULAN DAN SARAN}

Kami mereplikasi penelitian Herda \& Lavelle (2012) berdasarkan penelitian sebelumnya dan hasil dari komitmen organisasi dengan menggunakan sampel dari 110 orang auditor pada dua perusahaan akuntan publik berskala nasional. Pada dasarnya hasilnya konsisten dengan hasil dari penelitian sebelumnya. Hanya ada perbedaan signifikan didalam metodologi KUT yang kami gunakan, sebuah alternative pengukuran komitmen yang baru diperkenalkan di literatur organisasi. Selagi tidak ada masalah validitas yang serius dengan pengukuran komitmen sebelumnya, metode KUT memberikan keuntungan untuk penelitian akuntansi yang dapat dipertimbangkan.

Keuntungan yang utama dari KUT untuk penelitian akuntansi singkatnya adalah KUT terdiri dari 4 item, dibandingkan dari 15 hingga 9 dalam pendekatan Mowday-Porter dan 18 untuk pendekatan Allan - Meyer. Sebagai tambahan, kejelasan konseptual dan kebebasan target KUT sangat menarik. Ketika memeriksa target selain dari organisasi yang mempekerjakan, modifikasi skala kecil diperlukan dalam penggunaan KUT dibandingkan pengukuran komitmen tradisional. KUT mengizinkan penelitian akuntansi untuk 
mempelajari target komitmen tambahan yang sebelumnya belum dijelajahi dalam literatur akuntansi.

Penelitian akuntansi sebelumnya menunjukkan bahwa akuntan dapat berkomitmen untuk berbagai target yang ditetapkan oleh perusahaan mereka(Harsanti \& Whetyningtyas, 2014), (Sarsiti, 2013), (Tarigan, Bangun, \& Susanti, 2013), (Doina \& Iconia, 2015), (Dewi \& Budiartha, 2015). Literatur organisasi menyarankan bahwa individu juga dapat berkomitmen untuk kerja tim, atasan dan rekan kerja (Wulandari \& Nuryanto, 2018). Pada penelitian kami ini belum membahas penelitian komitmen akuntan untuk kelompok kerja, tim yang terlibat, atau pengawas. Singkatnya, penelitian selanjutnya dapat menggunakan metode dari KUT, penelitian selanjutnya juga dapat mengembangkan penelitian ini dengan memeriksa komitmen auditor terhadap perusahaan mereka, profesi, klien, kerja tim, dan pengawasan. Informasi pada penelitian ini dapat kemudian digunakan untuk mengevaluasi pengaruh dari komitmen pada hasil seperti kinerja, kepatuhan, persetujuan klien, dan prilaku yang mengancam kualitas audit.

\section{DAFTAR PUSTAKA}

Aubert, F., Wang, J. J., \& Grudnitski, G. (2019). Convergence Consensus Analyst Earnings Estimates and Option Pricing in Modeling Material Accounting Misstatements. Review of Accounting and Finance, 18(1), 134-156.

https://doi.org/10.1108/RAF-052017-0101

Chaddha, S., \& Navjayot. (2017). Manpower Study: Analysis of a State Technical University. Journal of Organisation \& Human Behaviour, 6(3), 30-36. Retrieved from http://escweb.lib.cbs.dk/login?url=http://sea rch.ebscohost.com/login.aspx?dire $\mathrm{ct}=$ true $\& \mathrm{db}=\mathrm{bth} \& \mathrm{AN}=126454355$ \&site $=$ ehost-live

Desai, V., Xu, B., \& Zeng, T. (2016). Local Accounting Firms' Pricing Responses to Entry of The Big Four Accounting Firms into China. Journal of Accounting in Emerging Economies, 6(1), 50-68. https://doi.org/10.1108/jaee-062013-0030

Dewi, D. A. C., \& Budiartha, I. K. (2015). Pengaruh Kompetensi dan Independensi Auditor pada Kualitas Audit Dimoderasi oleh Tekanan Klien. E-Jurnal Akuntansi Universitas Udayana, 11(1), 197210.

Doina, L. E., \& Iconia, T. A. (2015). Human Resources Audit- Primary Function of The Resources Management. Anale. Seria Stiinte Economice, 21(1), 188-190.

Harsanti, P., \& Whetyningtyas, A. (2014). Pengaruh Kompetensi, Independensi, dan Profesionalisme Auditor terhadap Kualitas Audit (Studi Empiris pada Kantor Akuntan Publik di Semarang). Jurnal Sosial Dan Budaya, 7(1), 16.

Herda, D. ., \& Lavelle, J. . (2012). The Auditor-Audit Firm Relationship and Its Effect on Burnout and Turnover Intention. Accounting Horizons, 26(4), 707-723.

Hullah, A. R. (2012). Pengaruh Sumber Daya Manusia dan Pemanfaatan Teknologi Informasi Terhadap Keterandalan Pelaporan Keuangan pada Pemerintah Provinsi Sulawesi Utara. Jurnal Riset Akuntansi Dan Auditing, 3(2).

Maslova, E. V., Kulchitskya, E. V., Melyakova, E. V., Kizyan, N. G., \& Penzina, O. S. (2017). Model of an organization's internal environment development on the basis of human resource audit. 
Journal of Advanced Research in Law and Economics, 8(1), 118127.

https://doi.org/10.14505/jarle.v8.1( 23). 14

Mitrík, K. (2019). Achieving Audit Quality : A Path Lined With Obstacles, As Well As Treasures. International Journal of Government Auditing, 46(3), 4-6.

Ravas, B. (2015). Simulation of Internal Audit Within the Department of Human Resources in an Economic Entity From the Public Sector. Annals of the University of Petrosani : Economics, 15(2), 143150.

Sarsiti. (2013). Pengaruh Persepsi Pengalaman Auditor dan Independensi Auditor terhadap Kualitas Audit (Studi Kasus Mahasiswa Akuntansi Di Universitas Surakarta). 2(2), 6790.

Singgih, D. W., Yuliati, N. N., \& Amrul, R. (2017). Pengaruh Pengendalian Internal dan Integritas pada Kecenderungan Kecurangan Akuntansi (Studi Kasus Pada Dinas SKPD Kota Mataram). Jurnal
Aplikasi Akuntansi, 2(1), 42-61. https://doi.org/10.29303/jaa.v2i1.9

Tarigan, M. U., Bangun, P., \& Susanti. (2013). Pengaruh Kompetensi, Etika, dan Fee Audit terhadap Kualitas Audit. Jurnal Akuntansi, 13(1), 803-832.

Wisdom, O., \& Oyebisi, O. M. (2017). Impact of Public Sector Auditing in Promoting Accountability and Trasparency in Nigeria. Journal of Internet Banking and Commerce, 22(3), 1-8.

Wulandari, D. N., \& Nuryanto, M. (2018). The Effect Of Internal Control, Anti-Fraud Awareness, Integrity, Independence, And Profesionalism To Fraud Prevention. Jurnal Riset Akuntansi Mercu Buana, 4(2), 117125.

https://doi.org/10.26486/jramb.v4i 2.557

Zucolotto, R., \& Teixeira, M. A. C. (2014). Budgetary Transparency and Democracy: The Effectiveness of Control Institutions. International Business Research, 7(6), 83-96. https://doi.org/10.5539/ibr.v7n6p8 3 